Article

\title{
Influence of Temperature and Preserving Agents on the Stability of Cornelian Cherries Anthocyanins
}

\author{
Bianca Moldovan and Luminiţa David * \\ "Babeş-Bolyai" University, Faculty of Chemistry and Chemical Engineering, 11, Arany Janos Str., \\ 400028 Cluj-Napoca, Romania; E-Mail: bianca@chem.ubbcluj.ro \\ * Author to whom correspondence should be addressed; E-Mail: muntean@chem.ubbcluj.ro; \\ Tel.: +40-264-593833 (ext. 5732); Fax: +40-264-590818.
}

Received: 2 April 2014; in revised form: 29 May 2014 / Accepted: 10 June 2014 /

Published: 17 June 2014

\begin{abstract}
Cornelian cherry (Cornus mas L.) fruits are known for their significant amounts of anthocyanins which can be used as natural food colorants. The storage stability of anthocyanins from these fruit extracts, at different temperatures $\left(2{ }^{\circ} \mathrm{C}, 25^{\circ} \mathrm{C}\right.$ and $\left.75^{\circ} \mathrm{C}\right)$, $\mathrm{pH} 3.02$, in the presence of two of the most widely employed food preserving agents (sodium benzoate and potassium sorbate) was investigated. The highest stability was exhibited by the anthocyanin extract stored at $2{ }^{\circ} \mathrm{C}$ without any added preservative, with half-life and constant rate values of $1443.8 \mathrm{~h}$ and $0.48 \times 10^{-3} \mathrm{~h}^{-1}$, respectively. The highest value of the degradation rate constant $\left(82.76 \times 10^{-3} / \mathrm{h}\right)$ was obtained in the case of anthocyanin extract stored at $75{ }^{\circ} \mathrm{C}$ without any added preservative. Experimental results indicate that the storage degradation of anthocyanins followed first-order reaction kinetics under each of the investigated conditions. In aqueous solution, the food preservatives used were found to have a slight influence on the anthocyanins' stability.
\end{abstract}

Keywords: anthocyanins; degradation kinetics; potassium sorbate; sodium benzoate

\section{Introduction}

Cornelian cherry (Cornus mas L.) is a species of dogwood native to Southern Europe and Southwest Asia. The fruit is an oblong, red drupe, 2-3 cm long, containing a single seed, edible, but astringent when unripe. Fresh cornelian cherry fruits contain twice as much ascorbic acid (vitamin C) as oranges, being also rich in sugar, organic acids and tannins [1]. Cornelian cherry fruits also contain 
significant amounts of anthocyanins which are known to possess antioxidant and anti-inflammatory effects. The most popular application of cornelian cherries is in different drinks, gels and jams, but they can also be eaten fresh, dried whole or pickled. The use of Cornelian cherries for the medical treatment of gastrointestinal disorders and diarrhea has been reported [2]. The anti-bacterial, anti-histamine, anti-allergic, anti-microbial and anti-malarial properties of the fruits are also known [3]. In Europe, Cornelian cherry fruits were reported to have food and cosmetic applications [4]. Because of their health benefits, there are several reports about Cornelian cherry fruits, especially regarding their physical and chemical properties, as well as their polyphenolic, ascorbic acid and anthocyanin contents [5].

Anthocyanins are a class of naturally occurring phenols, being the largest group of water-soluble pigments in plants. Many edible plants are sources of anthocyanins [6-8]. These compounds play a significant role in the color of many fruits, flowers, vegetables and products derived from them. In recent years, various important biological activities, such as antioxidant, antimutagenic, anticancer, anti-inflammatory and antiobesity properties of anthocyanins have been reported [9-12]. The bright color of anthocyanins (orange, red, purple, blue), ensures a high potential of being used as natural colorants, as a healthy alternative to synthetic dyes. Color directly affects the appearance and the consumer acceptability of the fruits and their derived products.

The color of anthocyanins depends essentially on the different structural forms in which they can be found, these structures being strongly influenced by the $\mathrm{pH}$ value. At $\mathrm{pH}$ values between 4 and 6 (typical for fresh and processed fruits) a mixture of equilibrium forms of anthocyanins: red flavylium cation (I), blue anhydrous quinoidal base (IV), colorless carbinol pseudobase (II) and yellow chalcone (III) coexists (Scheme 1).

Scheme 1. Chemical structures of anthocyanins at different $\mathrm{pH}$ values.<smiles></smiles><smiles>[R10]Oc1cc(=O)cc2oc(-c3cc([Z7])c(O)c([Y7])c3)c(O[R10])cc1-2</smiles><smiles>[Z7]OC1=Cc2c(O[R1])cc(O)cc2OC1(O)c1cc([Y7])c(O)c([Z7])c1</smiles>

$$
\begin{aligned}
& \mathrm{R}^{1}=\mathrm{H} \text { or glycosyl } \\
& \mathrm{R}^{2}=\text { glycosyl } \\
& \mathrm{R}^{3^{\prime}}, \mathrm{R}^{5^{\prime}}=\mathrm{H}, \mathrm{OH} \text { or } \mathrm{OCH}_{3}
\end{aligned}
$$


Anthocyanins easily convert to undesirable colorless or brown compounds as a consequence of their high reactivity. The anthocyanin stability can be influenced by many factors, the most important being temperature. The light, $\mathrm{pH}$ value, presence of oxygen, ascorbic acid, sugars, hydrogen peroxide and enzymes also affect the stability of these natural pigments [13-18].

Thus, investigation of anthocyanins degradation and measurement of their content at various intervals of storage offers useful experimental information for the food industry. However, to date, no information is available in the literature on the degradation kinetics of Cornelian cherry anthocyanins. The accurate determination of the degradation kinetics for these compounds during storage or thermal processing is essential for predicting changes that may occur in food products containing these anthocyanins.

Sodium benzoate and potassium sorbate are used as food preservatives due to their antimicrobial properties. They are widely used in foods such as soft drinks, jams and fruit juices. Although the effect of these compounds on the inactivation of bacterial pathogens in fruit juices was reported [19], the influence of these synthetic food preserving agents on anthocyanin degradation has been little investigated. Thakur and Araya tested the effect of sodium benzoate and sorbate on the stability of blue grape anthocyanins during storage at $15-35{ }^{\circ} \mathrm{C}[20]$, indicating that the stability of the anthocyanins after 60 days was higher in samples preserved with sorbate than with benzoate.

The objective of the present study was to evaluate the influence of temperature and these two commonly used synthetic food preservatives on the stability of Cornelian cherry anthocyanins. The investigated conditions (temperature and nature of an added preservative) ensure a high compatibility with processing techniques often applied in the food industry.

\section{Results and Discussion}

The influence of temperature and food preserving agents on the stability of anthocyanins from the Cornelian cherry fruits extract during storage was investigated. The determined values for the kinetic parameters (kinetic rate constants and the half-life values) are summarized in Table 1.

Table 1. Kinetic parameters of degradation of anthocyanins from Cornelian cherriesextracts in different conditions.

\begin{tabular}{cccc}
\hline Sample & Temp. $\left({ }^{\circ} \mathbf{C}\right)$ & $\left.\mathbf{k} \cdot \mathbf{1 0}^{-\mathbf{3}} \mathbf{( h}^{-\mathbf{1}}\right)^{\mathbf{1}}$ & $\mathbf{t}_{\mathbf{1} / 2} \mathbf{( h )}$ \\
\hline Crude extract & 2 & $0.48(0.9632)$ & $1443.75^{\mathrm{a}}$ \\
Extract+sodium benzoate & 2 & $0.57(0.9733)$ & $1215.78^{\mathrm{b}}$ \\
Extract+potassium sorbate & 2 & $0.65(0.9903)$ & $1066.15^{\mathrm{c}}$ \\
Crude extract & 22 & $0.87(0.9188)$ & $796.55^{\mathrm{a}}$ \\
Extract+sodium benzoate & 22 & $0.93(0.9739)$ & $745.16^{\mathrm{b}}$ \\
Extract+potassium sorbate & 22 & $1.13(0.9703)$ & $613.27^{\mathrm{c}}$ \\
Crude extract & 75 & $82.61(0.9922)$ & $8.38^{\mathrm{a}}$ \\
Extract+sodium benzoate & 75 & $78.84(0.9908)$ & $8.78^{\mathrm{a}}$ \\
Extract+potassium sorbate & 75 & $77.35(0.9912)$ & $8.95^{\mathrm{a}}$ \\
\hline
\end{tabular}

${ }^{1}$ Numbers in parentheses, $\mathrm{R}^{2}$, are the determination coefficients; ${ }^{2}$ Values within a column with different superscript letters are significantly $(p<0.05)$ different in the same temperature group.

The content of anthocyanins from Cornelian cherries aqueous extract during storage at different temperatures $\left(2{ }^{\circ} \mathrm{C}, 22^{\circ} \mathrm{C}\right.$ and $\left.75^{\circ} \mathrm{C}\right)$ were plotted as a function of time. The initial total content of the 
extract was $68.68 \pm 0.088 \mathrm{mg} / \mathrm{L}$. The linear regression of the total anthocyanins content of Cornelian cherry fruits extracts during storage confirmed that the degradation process of these pigments followed first order reaction kinetics. These results are in agreement with previously reported literature data [15,21-24] that indicated first order reaction kinetics for the storage and thermal degradation of anthocyanins from various sources.

The thermal stability of the extracts was evaluated. As expected, the increase of storage temperature $\left(22^{\circ} \mathrm{C}\right)$ resulted in a 1.8 times faster degradation as compared to refrigerated storage $\left(\right.$ at $\left.2{ }^{\circ} \mathrm{C}\right)$ while, at $75^{\circ} \mathrm{C}$, the degradation rate was 172.1 times higher.

The total content of anthocyanins from Cornelian cherries extracts stored at $2{ }^{\circ} \mathrm{C}$ was plotted as a function of time (Figure 1). By comparing the half-life values, one can conclude that, the presence of food preservatives displayed a slightly destabilizing effect on the anthocyanins from the investigated extracts.

Figure 1. Influence of different food preservatives on the anthocyanin stability during storage at $2{ }^{\circ} \mathrm{C}$ (vertical lines represent $\left.\mathrm{SD}, n=4\right)$.

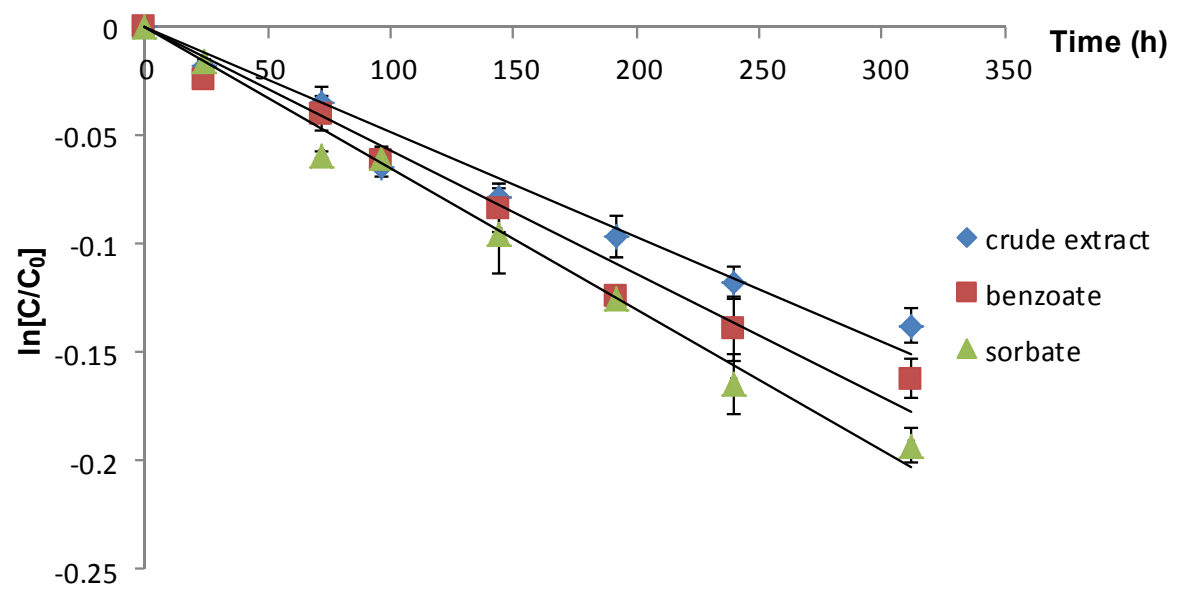

However, the difference between the two added food preservatives was not significant, the degradation process being 1.14 fold faster in the presence of potassium sorbate as compared to sodium benzoate.

As observed in the case of refrigerated storage, the Cornelian cherry anthocyanins stored at $22{ }^{\circ} \mathrm{C}$ showed the same degradation profile (Figure 2). In this case, storage of the extracts in the presence of potassium sorbate resulted in faster degradation compared to storage with added sodium benzoate, the value of the half-life ratio being 1.21 .

As expected, the increase of temperature at $75{ }^{\circ} \mathrm{C}$ resulted in an accelerated degradation of anthocyanins. During high temperature storage, as applied at $75^{\circ} \mathrm{C}$, the destabilizing effect of sodium benzoate and potassium sorbate on the anthocyanin pigments (observed at lower storage temperatures) was not evident. In contrast, the added food preserving agents had almost no influence on the stability of these pigments (Figure 3), the half-life values being practically the same for all the investigated extracts $(8.4 \div 8.95 \mathrm{~h})$.

The effect of temperature on the kinetics of the degradation process was determined by fitting the rate constants to an Arrhenius type equation. 
Figure 2. Influence of different food preservatives on the anthocyanin stability during storage at $22{ }^{\circ} \mathrm{C}$ (vertical lines represent $\mathrm{SD}, n=4$ ).

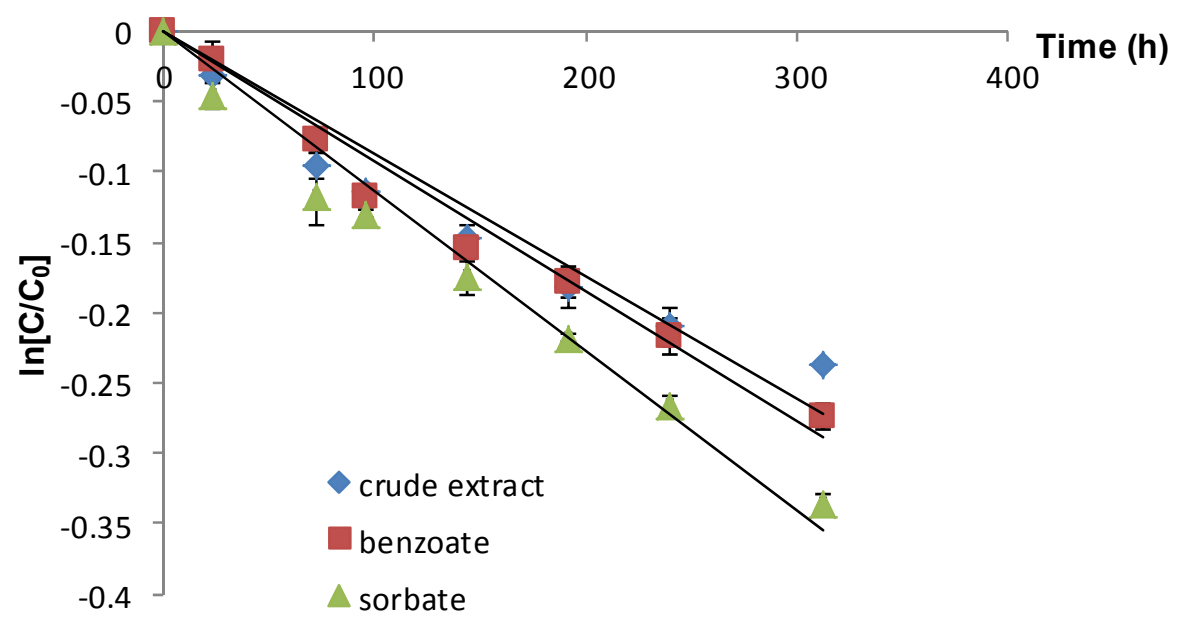

Figure 3. Influence of different food preservatives on the anthocyanin stability during storage at $75^{\circ} \mathrm{C}$ (vertical lines represent $\mathrm{SD}, n=4$ ).

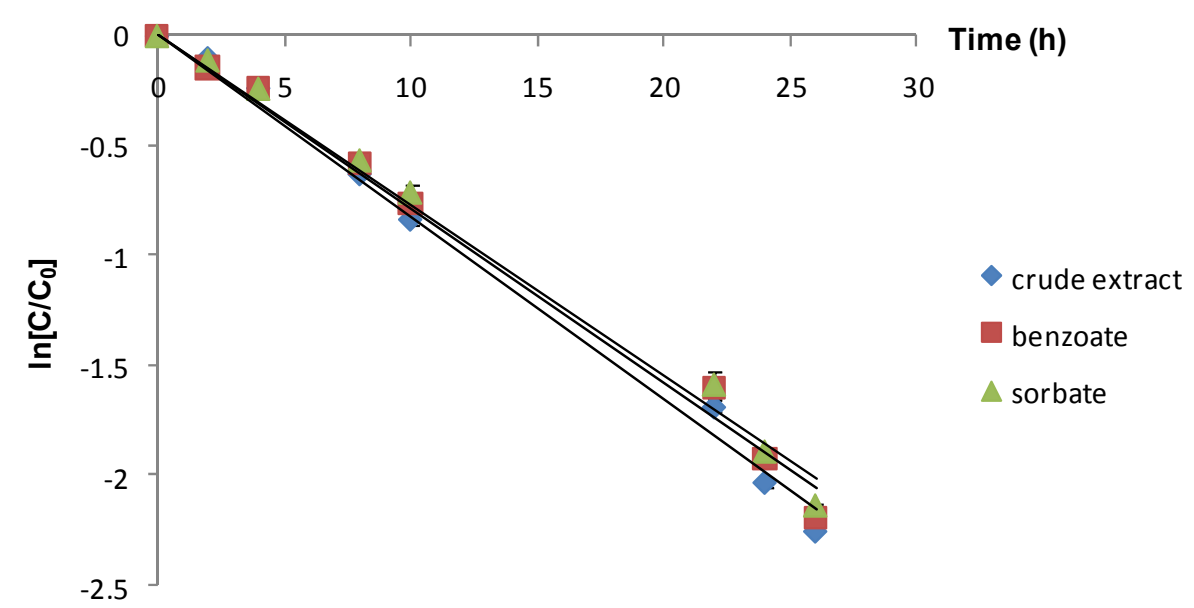

The anthocyanin degradation rate constants obtained for each extract were plotted as a function of temperature (Figure 4).

Figure 4. The Arrhenius plots for degradation of anthocyanins in Cornelian cherries extracts.

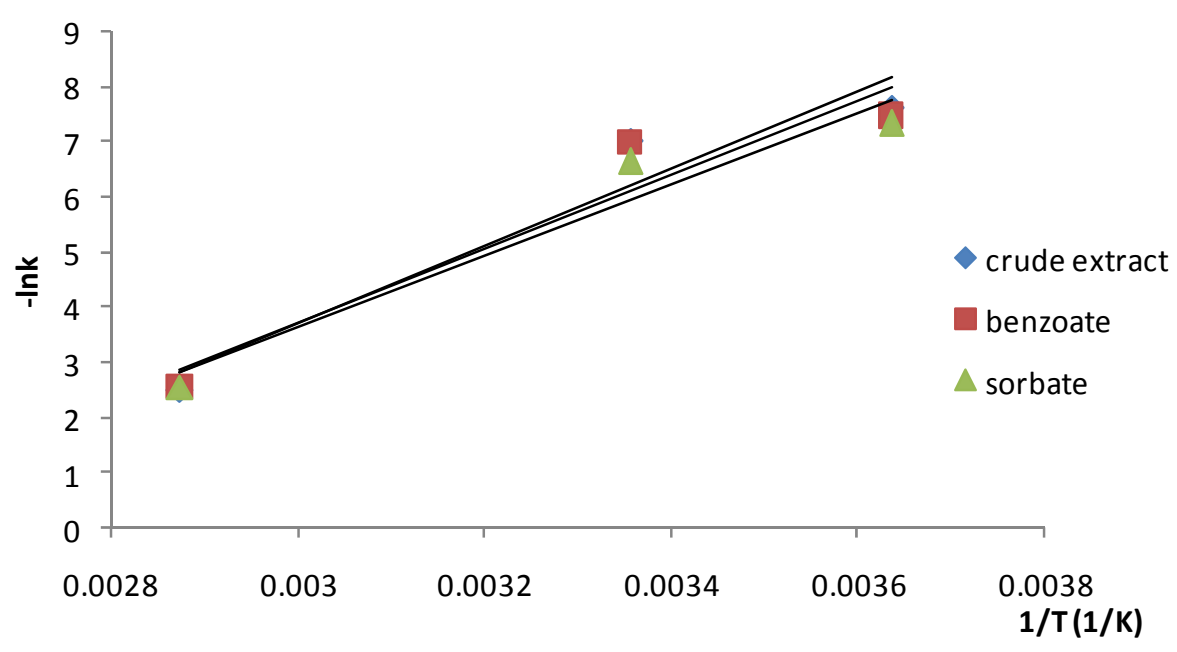


The calculated activation energies $\left(E_{a}\right)$, frequency factors $\left(K_{o}\right)$ and the temperature coefficients $\left(\mathrm{Q}_{10}\right)$ are given in Table 2 .

Table 2. Effect of temperature on the degradation of anthocyanins from Cornelian cherry fruits extracts.

\begin{tabular}{|c|c|c|c|c|}
\hline \multirow{2}{*}{ Solvent } & \multirow{2}{*}{$E_{a}(k J / m o l)^{a}$} & \multirow{2}{*}{$K_{0}\left(h^{-1}\right)$} & \multicolumn{2}{|c|}{$\mathbf{Q}_{10}$} \\
\hline & & & $2-22{ }^{\circ} \mathrm{C}$ & $22-75^{\circ} \mathrm{C}$ \\
\hline Crude extract & $58.55(0.9307)$ & $3.72 \times 10^{7}$ & 1.346 & 2.361 \\
\hline Extract + sodium benzoate & $56.21(0.9226)$ & $1.57 \times 10^{7}$ & 1.277 & 2.311 \\
\hline Extract + potassium sorbate & $54.09(0.9446)$ & $7.9 \times 10^{6}$ & 1.318 & 2.219 \\
\hline
\end{tabular}

${ }^{\mathrm{a}}$ Numbers in parentheses, $\mathrm{R}^{2}$, are the determination coefficients.

Since high activation energy reactions are more sensitive to temperature, the anthocyanins in the extract proved to be more susceptible to degradation by exposure to elevated temperatures. The calculated $E_{a}$ values ranged from 54.09 to $58.55 \mathrm{~kJ} / \mathrm{mol}$. The highest influence of the temperature on the stability of the investigated compounds (the highest value of $E_{a}$ ) was observed for the anthocyanins stored in the crude extract, while the pigments stored in the presence of potassium sorbate exhibited lower susceptibility to thermal degradation, presenting the lowest value of the $\mathrm{E}_{\mathrm{a}}$. The low differences between the activation energy values suggested that the added synthetic preservatives exhibited a slightly influence on the stability of anthocyanins.

In order to evaluate the dependence of degradation rate on temperature, the temperature coefficient $\mathrm{Q}_{10}$ (the change of degradation rate upon a temperature increase of $10 \mathrm{~K}$ ) was calculated.

Higher $\mathrm{Q}_{10}$ values for storage temperatures of $22-75^{\circ} \mathrm{C}$ were obtained, indicating that anthocyanins are more sensitive to temperature elevations at high storage temperatures compared to low storage temperatures $\left(2-22^{\circ} \mathrm{C}\right)$ where the $\mathrm{Q}_{10}$ values were ranged from 1.277 to 1.346 , whereas the differences were insignificant. The lowest temperature coefficient value $\left(1.277\right.$ at $\left.2-22{ }^{\circ} \mathrm{C}\right)$ was obtained for the anthocyanins stored in the presence of sodium benzoate. Almost the same $\mathrm{Q}_{10}$ values were obtained for the degradation of anthocyanins stored at $2-22{ }^{\circ} \mathrm{C}$ for all the investigated extracts (crude or with added preservative), proving that the influence of the added food preserving agents was not significant. Storage at $22-75{ }^{\circ} \mathrm{C}$ resulted in higher $\mathrm{Q}_{10}$ values the calculated temperature coefficients for this storage interval presenting almost the same value for all the investigated extracts. Higher $\mathrm{Q}_{10}$ values indicate that at high storage temperatures $\left(22-75^{\circ} \mathrm{C}\right)$ anthocyanins are more sensitive to temperature elevations than at low storage temperatures $\left(2-22^{\circ} \mathrm{C}\right)$.

All these results clearly indicate that low storage temperatures are required to inhibit the degradation process of these pigments from Cornelian cherry extracts.

Significantly different temperature coefficients $\mathrm{Q}_{10}$ for the two investigated temperature intervals, may be due to a possible change in the reaction mechanism of the degradation of Cornelian cherries anthocyanins at elevated temperatures, such as $75{ }^{\circ} \mathrm{C}$, compared to low temperature degradation process. The high ascorbic acid content of Cornelian cherry fruits [1] could accelerate the degradation of anthocyanins. The loss of anthocyanins caused by ascorbic acid (AA) occurs due to the free radical oxidative cleavage of the pyrilium ring in which AA acts as molecular oxygen activator. At high temperatures, AA itself undergoes a degradation process, generating degradation products which are 
also responsible for anthocyanins degradation [25]. Since no degradation studies were performed on the Cornelian cherry anthocyanins, the determined $t_{1 / 2}$ values are compared to the literature reported data for the degradation process of anthocyanins obtained from other fruits. Wang and Xu reported that the $\mathrm{t}_{1 / 2}$ value for anthocyanin degradation in blackberry juice at $\mathrm{pH} 2.86$ was $4.7 \mathrm{~h}$ at $80{ }^{\circ} \mathrm{C}$ [23]. In blood orange juice concentrate, the reported $t_{1 / 2}$ value at $4{ }^{\circ} \mathrm{C}$ was 55.7 days [26]. Compared to this value, our results are in the same range $\left(\mathrm{t}_{1 / 2}=60.2\right.$ days at $\left.2{ }^{\circ} \mathrm{C}\right)$. The major anthocyanins in Cornelian cherries are cyanidin-3-O-galactoside, pelargonidin-3-O-galactoside and delphinidin-3-O-galactoside [3]. However, the major anthocyanins in blackberry are cyanidin-3-O-glucoside, cyanidin-3-O-rutinoside and cyanidin-3-O-malonyl-glucoside [27,28]. Therefore, the different stability of the anthocyanins might be due to the varying composition of the fruit extracts; the major constituents of these extracts being sugars, ascorbic acid, and flavonoids, which are known to be intrinsic factors that influence anthocyanins degradation [29]. It could be concluded that Cornelian cherry anthocyanins are more stable than anthocyanins from other sources (e.g., blackberry), proving a quite good stability during storage and heating, indicating a potential use of these pigments as natural colorants in food industry.

\section{Experimental}

\subsection{Materials}

\subsubsection{Plant Material}

Samples of Cornelian cherry fruits were purchased in August 2012 from a local market in Cluj-Napoca, Romania. Fruits were packed in polyethylene bags and kept frozen at $-18{ }^{\circ} \mathrm{C}$ before being subjected to extraction of anthocyanins.

\subsubsection{Chemicals and Reagents}

Potassium chloride, sodium acetate, acetic acid and $\mathrm{HCl}$ conc., were purchased from Merck (Darmstadt, Germany). Sodium benzoate and potassium sorbate were purchased from Chimopar (Bucharest, Romania). All chemicals and reagents were of analytical grade and were used without further purification. The distilled water was obtained using a TYPDP1500 Water distiller (Techosklo LTD, Držkov, Czech Republic).

\subsection{Methods}

\subsubsection{Preparation of Anthocyanin Extract}

Fifty grams of frozen Cornelian cherry fruits were crushed in a mortar. Thirty five $g$ of fruit puree were transferred to an Erlenmeyer flask and distilled water $(200 \mathrm{~mL})$ and concentrated $\mathrm{HCl}(0.25 \mathrm{~mL})$ were added. The mixture was stirred for $1 \mathrm{~h}$ at room temperature and then filtered. The residue was washed twice with extraction solvent (acidified water, $20 \mathrm{~mL}$ ). The filtrate was quantitatively transferred to a $250 \mathrm{~mL}$ volumetric flask and made up to $250 \mathrm{~mL}$ with solvent. The $\mathrm{pH}$ of the extract was determined using a Hanna Instruments (HI) $99161 \mathrm{pH}$-meter and the measured value was 3.02. 


\subsubsection{Determination of Anthocyanin Content}

The total anthocyanin content was determined using optical spectroscopy, by the convenient method of Giusti and Wrolstad [30]. This method is based on the structural changes of the pigments as a function of $\mathrm{pH}$. At $\mathrm{pH}=1$, the red to purple oxonium form predominates while at $\mathrm{pH}=4.5$ the major structural form is the colourless hemiketal. The difference in absorbance of the anthocyanin solutions at these two $\mathrm{pH}$ values permits an accurate and rapid determination of total monomeric anthocyanin content in the sample matrix. The two desired $\mathrm{pH}$ values were reached using two buffer systems: potassium chloride buffer $(0.025 \mathrm{M}, \mathrm{pH}=1.0)$ and sodium acetate buffer $(0.04 \mathrm{M} ; \mathrm{pH}=4.5)$.

Aliquots of Cornelian cherry fruits extract $(5 \mathrm{~mL})$ were transferred to a $10 \mathrm{~mL}$ volumetric flask, made up to $10 \mathrm{~mL}$ with corresponding buffer $(\mathrm{pH}=1$ and $\mathrm{pH}=4.5)$ and allowed to equilibrate for $15 \mathrm{~min}$. The absorbance of each equilibrated solution was then measured at 506 (the wavelength where the maximum of absorbance occurs $=\lambda_{\text {VIS } \max }$ ) and $700 \mathrm{~nm}$ (for haze correction), using an UV-VIS Perkin Elmer Lambda 25 double beam spectrophotometer.

Pigment content was calculated using a molar extinction coefficient of $26,900 \mathrm{~L} / \mathrm{mol} \cdot \mathrm{cm}$ and a molecular weight of $449.2 \mathrm{~g} / \mathrm{mol}$ (cyanidin-3-glucoside). Results were expressed as $\mathrm{mg}$ cyanidin-3-glucoside equivalents $\cdot \mathrm{L}^{-1}$ extract. Visible spectra of samples were recorded by scanning the absorbance between 400 and $700 \mathrm{~nm}$. Quartz cuvettes of $1 \mathrm{~cm}$ path length were used. Absorbance readings were performed against distilled water as a blank. All the measurements were carried out at room temperature $\left(\sim 22^{\circ} \mathrm{C}\right)$.

The total anthocyanin content (expressed as cyanidin-3-glucoside equivalents), was calculated from the experimental data, using the following equation [30]:

$$
T A=\frac{A \cdot M W \cdot D F \cdot 1000}{\varepsilon \cdot l}
$$

where: $\mathrm{TA}=$ total anthocyanin content $(\mathrm{mg} / \mathrm{L}) ; \mathrm{A}=$ absorbance, calculated as: [Equation (6)]

$$
\mathrm{A}=\left(\mathrm{A}_{\mathrm{pH} 1.0}-\mathrm{A}_{\mathrm{pH}} 4.5\right) 506 \mathrm{~nm}-\left(\mathrm{A}_{\mathrm{pH} 1.0}-\mathrm{A}_{\mathrm{pH} 4.5}\right) 700 \mathrm{~nm}
$$

$\mathrm{MW}=$ molecular weight; $\mathrm{DF}=$ dilution factor; $1=$ path length; $\varepsilon=$ molar extinction coefficient; $1000=$ conversion factor from grams to milligrams.

Four determinations $(n=4)$ were performed for each analysis and the average values of total anthocyanin content were used for kinetic parameters determination.

\subsubsection{Degradation Studies}

The influence of temperature on the storage stability was studied at $2{ }^{\circ} \mathrm{C}, 22{ }^{\circ} \mathrm{C}$ and $75{ }^{\circ} \mathrm{C}$. Each extract was divided into $50 \mathrm{~mL}$ portions and kept away from light (well capped to avoid evaporation) at $2{ }^{\circ} \mathrm{C}$ (in refrigerator), at room temperature $\left(22{ }^{\circ} \mathrm{C}\right)$ and in a thermostatic water bath, preheated to $75^{\circ} \mathrm{C}$, respectively $\left( \pm 1^{\circ} \mathrm{C}\right)$.

To test the influence of food preservatives on the thermal stability of anthocyanins from Cornelian cherry fruits extract, sodium benzoate or potassium sorbate was dissolved in the fruits extract at a final concentration of $1 \mathrm{~g} / \mathrm{L}$. 
Changes in total anthocyanin content of the samples were measured in order to evaluate the stability of the pigments in the investigated extracts. Samples were analyzed at 0, 1, 3, 4, 6, 8, 10 and 13 days for all extracts except for those stored at $75{ }^{\circ} \mathrm{C}$, which were sampled at $0,2,4,8,10,22,24$ and $26 \mathrm{~h}$. The storage intervals were different for the last thermal treatment due to the differences in anthocyanin degradation rates.

\subsubsection{Degradation Kinetics}

The kinetics for the degradation reaction of the investigated anthocyanins can be expressed by the equations:

$$
\begin{aligned}
\ln [\mathrm{TA}] & =\ln \left[\mathrm{TA}_{0}\right]-\mathrm{kt} \\
\mathrm{t}_{1 / 2} & =-\ln 0.5 / \mathrm{k}
\end{aligned}
$$

where: $[\mathrm{TA}]=$ total anthocyanin content $(\mathrm{mg} / \mathrm{L})$ at time $\mathrm{t} ;\left[\mathrm{TA}_{0}\right]=$ initial total anthocyanin content $(\mathrm{mg} / \mathrm{L}) ; \mathrm{k}=$ reaction rate constant $\left(\mathrm{h}^{-1}\right) ; \mathrm{t}=$ reaction time $(\mathrm{h}) ; \mathrm{t}_{1 / 2}=$ half-life $(\mathrm{h})$.

The effect of temperature on the kinetics of the degradation process was determined by fitting the rate constants to an Arrhenius type equation [Equation (5)]:

$$
\mathrm{k}=\mathrm{K}_{0} \mathrm{e}^{-\mathrm{Ea} / \mathrm{RT}}
$$

where: $\mathrm{k}=$ rate constant $\left(\mathrm{h}^{-1}\right) ; \mathrm{K}_{0}=$ frequency factor $\left(\mathrm{h}^{-1}\right) ; \mathrm{E}_{\mathrm{a}}=$ activation energy $(\mathrm{kJ} / \mathrm{mol})$; $\mathrm{R}=$ universal gas constant $(8.314 \mathrm{~J} / \mathrm{mol} \cdot \mathrm{K}) ; \mathrm{T}=$ absolute temperature $(\mathrm{K})$.

The $\mathrm{Q}_{10}$ temperature coefficient was calculated according to Equation (6):

$$
Q_{10}=\left(\frac{k_{2}}{k_{1}}\right)^{10 /\left(T_{2}-T_{1}\right)}
$$

where: $\mathrm{Q}_{10}=$ the temperature coefficient $\left(\mathrm{K}^{-1}\right) ; \mathrm{k}_{1,2}=$ rate constant $\left(\mathrm{h}^{-1}\right)$ at temperature $\mathrm{T}_{1,2}(\mathrm{~K})$.

\subsection{Statistical Analysis}

Data are reported as mean values of at least four experiments. Results were analyzed using one-way variance analysis (ANOVA). Analysis of variance was performed using XLSTAT Release 10 (Addinsoft, Paris, France). Differences at $p<0.05$ were considered statistically significant.

\section{Conclusions}

The total anthocyanin content of Cornelian cherries and the storage stability of these compounds indicated that these fruits can be used as an important source of natural red pigment for the food industry. The results of the present study have provided detailed information on the degradation kinetic parameters of anthocyanins during storage and heating. Increasing the temperature resulted in higher degradation rate constants: the degradation rate of anthocyanins from Cornelian cherries extract at $22{ }^{\circ} \mathrm{C}$ was 1.8 times faster than at $2{ }^{\circ} \mathrm{C}$, while at $75^{\circ} \mathrm{C}$ this process was 172 times faster than at $2{ }^{\circ} \mathrm{C}$. Comparison of the rate constants and half-life values showed that the anthocyanin stability was slightly influenced by the kind of the added organic food preservative. 


\section{Acknowledgments}

This research was supported by the Ministry of Education, Research, Youth and Sports, Romania (project No. 147/2011 PN-II-PT-PCCA-2011-3-1-0914).

\section{Author Contributions}

Luminiţa David, as leading author, has been involved in designing the research, interpreting the data, writing and revising the paper. Bianca Moldovan has been involved in performing the research, analyzing data as well as drafting the paper.

\section{Conflicts of Interest}

The authors declare no conflict of interest.

\section{References}

1. Seeram, N.P.; Schutzki, R.; Chandra, A.; Nair, M.G. Characterization, quantification and bioactivities of anthocyanins in Cornus species. J. Agric. Food Chem. 2002, 50, 2519-2523.

2. Celik, S.; Bakirci, I.; Sat, I.G. Physico-chemical and organoleptic properties of yogurt with cornelian cherry paste. Int. J. Food Prop. 2006, 9, 401-408.

3. Vareed, S.K.; Reddy, M.K.; Schutzki, R.E.; Nair, M.G. Anthocyanins in Cornus alternifolia, Cornus controversa, Cornus kousa and Cornus florida fruits with health benefits. Life Sci. 2006, 78, 777-784.

4. Polinicencu, C.; Popescu, H.; Nistor, C. Vegetal extracts for cosmetic use: Extracts from fruits of Cornus mas. Preparation and characterization. Clujul Med. 1980, 53, 160-163.

5. Pantelidis, G.E.; Vasilakakis, M.; Manganaris, G.A.; Diamantidis, G. Antioxidant capacity, phenol, anthocyanin and ascorbic acid contents in raspberries, blackberries, red currants, gooseberries and Cornelian cherries. Food Chem. 2007, 102, 777-783.

6. Mazza, G. Natural Food Colorants: Science and Technology; Marcel Decker: New York, NY, USA, 2000; pp. 289-314.

7. Reyes, L.F.; Cisneros-Zevallos, L. Degradation kinetics and colour of anthocyanins in aqueous extracts of purple- and red-flesh potatoes (Solanum tuberosum L.). Food Chem. 2007, 100, 885-894.

8. Prodanov, M.P.; Dominguez, J.A.; Blazquez, I.; Salinas, M.R.; Alonso, G.L. Some aspects of the quantitative/qualitative assessment of commercial anthocyanin-rich extracts. Food Chem. 2005, 90, 585-596.

9. Yoshimoto, M.; Okuno, S.; Yamaguchi, M.; Yamakawa, O. Antimutagenicity of Deacylated Anthocyanins in Purple-fleshed Sweetpotato. Biosci. Biotechnol. Biochem. 2001, 65, 1652-1655.

10. Tsuda, T.; Horio, F.; Uchida, K.; Aoki, H.; Osawa, T. Dietary cyanidin 3-O- $\beta$-D-glucoside-rich purple corn color prevents obesity and ameliorates hyperglycemia in mice. J. Nutr. 2003, 133, 2125-2130.

11. Smith, M.A.L.; Marley, K.A.; Seigler, D.; Singletary, K.W.; Meline, B. Bioactive Properties of Wild Blueberry Fruits. J. Food Sci. 2000, 65, 352-356. 
12. Crisan, M.; David, L.; Moldovan, B.; Vulcu, A.; Dreve, S.; Perde-Schrepler, M.; Tatomir, C.; Filip, A.G.; Bolfa, P.; Achim, M.; et al. New nanomaterials for the improvement of psoriatic lesions. J. Mater. Chem. B 2013, 1, 3152-3158.

13. Cevallos-Casalas, B.A.; Cisneros-Zevallos, L. Stability of anthocyanin-based aqueous extracts of Andean purple corn and red-fleshed sweet potato compared to synthetic and natural colorants. Food Chem. 2004, 86, 69-77.

14. Özkan, M.; Yemenicioğlu, A.; Asefi, N.; Cemeroğlu, B. Degradation kinetics of anthocyanins from sour cherry, pomegranate, and strawberry juices by hydrogen peroxide. J. Food Sci. 2002, $67,525-529$.

15. Hernández-Herrero, J.A.; Frutos, M.J. Degradation kinetics of pigment, colour and stability of the antioxidant capacity in juice model systems from six anthocyanin sources. Int. J. Food Sci. Technol. 2011, 46, 2550-2557.

16. Garzon, G.A.; Wrolstad, R.E. Comparison of the stability of pelargonidin-based anthocyanins in strawberry juice and concentrate. J. Food Sci. 2002, 67, 1288-1299.

17. Moldovan, B.; David, L.; Chisbora, C.; Cimpoiu, C. Degradation kinetics of anthocyanins from European Cranberrybush (Viburnum opulus L.) fruits extracts. Effects of temperature, $\mathrm{pH}$ and storage solvent. Molecules 2012, 17, 11655-11666.

18. Moldovan, B.; David, L.; Donca, R.; Chisbora, C. Degradation kinetics of anthocyanins from crude ethanolic extract from sour cherries. Stud. Univ. Babes-Bolyai Chem. 2011, 56, 189-194.

19. Gurtler, J.B.; Bailey, R.B.; Geveke, J.D.; Zhang, H.Q. Pulsed electric field inactivation of E. coli O157:H7 and non-pathogenic surrogate E. coli in strawberry juice as influenced by sodium benzoate, potassium sorbate, and citric acid. Food Control. 2011, 22, 1689-1694.

20. Thakur, B.R.; Arya, S.S. Studies on stability of blue grape anthocyanins. Int. J. Food Sci. Technol. 1989, 24, 321-326.

21. Chisté, R.C.; Lopes, A.S.; DeFaria, L.J.G. Thermal and light degradation kinetics of anthocyanin extracts from mangosteen peel (Garcinia mangostana L.). Int. J. Food Sci. Technol. 2010, 45, 1902-1908.

22. Kirca, A.; Özkan, M.; Cemeroğlu, B. Effects of temperature, solid content and $\mathrm{pH}$ on the stability of black carrot anthocyanins. Food Chem. 2007, 101, 212-218.

23. Wang, W.D.; Xu, S.Y. Degradation kinetics of anthocyanins in blackberry juice and concentrate. J. Food Eng. 2007, 82, 271-275.

24. Amaro, L.F.; Soares, M.T.; Pinho, C.; Almeida, I.F.; Pinho, O.; Ferreira, I.M. Processing and storage effects on anthocyanin composition and antioxidant activity of jams produced with Camarosa strawberry. Int. J. Food Sci. Technol. 2013, 48, 2071-2077.

25. Jackman, R.L.; Yada, R.Y.; Tung, M.A. A review: Separation and chemical properties of anthocyanins used for their qualitative and quantitative analysis. J. Food Biochem. 1987, 11, 279-308.

26. Kirca, A.; Cemeroğlu, B. Thermal degradation of blood orange anthocyanins. Food Chem. 2003, $81,583-587$.

27. Fang-Chiang, H.J.; Wrolstad, R.E. Anthocyanins pigment composition of blackberries. J. Food Sci. 2005, 70, 198-202. 
28. Rommel, A.; Wrolstad, R.E. Blackberry juice and wine: Processing and storage effects on anthocyanin, color and appearance. J. Food Sci. 1992, 57, 385-391

29. Cao, S.Q.; Liu, L.; Lu, Q.; Xu, Y.; Pan, S.Y.; Wang, K.X. Integrated effects of ascorbic acid, flavonoids and sugars on thermal degradation of anthocyanins in blood orange juice. Eur. Food Res. Technol. 2009, 228, 975-983

30. Giusti, M.M.; Wrolstad, R.E. Current Protocols in Food Analytical Chemistry; Wiley: New York, NY, USA, 2001; pp. 1-13.

Sample Availability: Samples of extracts are available for the next 2 months (the anthocyanins from the extracts totally degraded after this time period) from the authors.

(C) 2014 by the authors; licensee MDPI, Basel, Switzerland. This article is an open access article distributed under the terms and conditions of the Creative Commons Attribution license (http://creativecommons.org/licenses/by/3.0/). 